\title{
THE PLASMA VITAMIN $B_{12}$ BINDING SUBSTANCE: I. ITS DETECTION IN THE SEROMUCOID FRACTION OF PLASMA FROM NORMAL SUBJECTS AND PATIENTS WITH CHRONIC MYELO- CYTIC LEUKEMIA*
}

\author{
BY I. BERNARD WEINSTEIN, $\dagger$ SHERMAN M. WEISSMAN $\ddagger$ AND \\ DONALD M. WATKIN
}

\begin{abstract}
(From the Metabolism Service, National Cancer Institute, National Institutes of Health, Public Health Service, Bethesda, Md.)
\end{abstract}

(Submitted for publication May 25, 1959; accepted July 6, 1959)

It is well known that the striking increases in serum vitamin $B_{12}$ concentrations seen in patients with chronic myelocytic leukemia (CML) are associated with an increased plasma binding capacity for $B_{12}$. The latter has been demonstrated in vitro (1-4) using microbiologic assay or dialysis. In vivo studies in patients with CML have demonstrated a delay in the plasma disappearance of either an intravenously $(5,6)$ or orally $(7)$ administered dose of $\mathrm{Co}^{58} \mathrm{~B}_{12}$ and would appear to confirm the in vitro findings.

The association of a high serum $B_{12}$ with a high plasma binding capacity has stimulated investigation into the nature of the plasma binding substance. Previous attempts to characterize the $B_{12}$ binding substance have been primarily concerned with defining its electrophoretic mobility, and thus far actual isolation and chemical characterization have not been achieved $(1,8-10)$. The fact that $\mathrm{B}_{12}$ apparently exists in a macromolecular complex at several stages of its metabolism, including gastrointestinal absorption (11), plasma transport (1) and liver storage (12), led us to consider whether or not a similar type of substance binds $B_{12}$ in each case. Since intrinsic factor, which plays a key role in the gastrointestinal absorption of $B_{12}$, is thought to be a glycoprotein (13), we undertook the present studies to determine whether or not the $B_{12}$ binding substance of plasma is also a glycoprotein.

$\mathrm{Co}^{58}$ vitamin $\mathrm{B}_{12}$ was used to label the serum $\mathrm{B}_{12}$ binding protein, either in vitro or in vivo. Glyco-

\footnotetext{
* Presented before the Twenty-third Annual Meeting of the American Institute of Nutrition, Atlantic City, N. J., April 14, 1959.

$\dagger$ Present address: Department of Bacteriology and Immunology, Harvard Medical School, Boston, Mass.

$¥$ Present address: Department of Biochemistry, University of Glasgow, Scotland.
}

proteins were isolated according to modifications of the methods of Winzler, Weimer, and co-workers $(14,15)$. The results obtained with plasma from patients with CML were compared to those obtained with plasmas from subjects having normal serum $B_{12}$ concentrations. The latter were either normal bank blood donors or patients with malignant disease and normal serum $\mathrm{B}_{12}$ concentrations, and in the text are referred to as "control" subjects.

\section{METHODS}

Microbiologic assay. A modification described in detail elsewhere (16) of the U. S. P. method using Lactobacillus leichmannii, American Type Culture Collection No. 7830 , was utilized in measuring the $B_{12}$ concentrations of sera and serum fractions. The mean and standard error of $B_{12}$ levels determined by this method in 31 normal subjects was $0.533 \pm 0.030 \mathrm{~m} \mu \mathrm{g}$. per $\mathrm{ml} .^{1}$

Radioactivity assay. The $\mathrm{Co}^{\mathrm{s}} \mathrm{B}_{12}$ had an original specific activity of $2.38 \mu \mathrm{c}$. per $\mu \mathrm{g} .^{2}$ One m $\mu \mathrm{g}$. of this material gave approximately $1,900 \mathrm{cpm}$ above a background of $180 \mathrm{cpm}$. All counting was done in a well-type scintillation counter. Samples were counted for a period of time sufficient to give a counting error of less than 3 per cent.

Biologic activity of the labeled vitamin was confirmed by $L$. leichmannii assay and found to be 93 per cent of that given by the manufacturer. Suitable dilutions were made with the buffer described below.

Perchloric-phosphotungstic acid precipitation. The in vitro studies were done as follows. To $3 \mathrm{ml}$. aliquots of plasmas in dialysis bags was added $1 \mathrm{ml}$. of solutions containing sufficient $\mathrm{CO}^{88} \mathrm{~B}_{12}$ to provide concentrations ranging from 0.1 to $100 \mathrm{~m} \mu \mathrm{g}$. of $\mathrm{Co}^{\mathrm{8s}} \mathrm{B}_{12}$ per ml. of plasma. The bags were tied, and the contents mixed by inversion and incubated at room temperature for one hour. Each bag was placed in a $125 \mathrm{ml}$. Erlenmeyer flask and $100 \mathrm{ml}$. of buffer was added. ${ }^{3}$ Dialysis was performed for a total

1 The abbreviation m $\mu \mathrm{g}$. as used in this paper means $10^{-0}$ gram.

2 Purchased from Merck and Co., Inc., Rahway, N. J.

3 The buffer used was $0.15 \mathrm{M}$ sodium phosphate adjusted to $\mathrm{pH} 7.3$ and diluted with nine parts of 0.85 per cent sodium chloride. 
of 72 hours at $4^{\circ} \mathrm{C}$. with replacements of the buffer at 24 and 48 hours. The contents of each dialysis bag was transferred to a $4 \mathrm{ml}$. counting vial and counted against a standard. Each vial was then emptied into a $50 \mathrm{ml}$. beaker to which was added $18 \mathrm{ml}$. of 0.85 per cent saline. The saline facilitated rinsing of the vial and served to dilute out the glycoproteins, thus minimizing loss by coprecipitation with the perchloric acid precipitable proteins. Ten ml. of $1.8 \mathrm{M}$ perchloric acid was slowly added to each beaker with mixing and five minutes later the contents filtered through Whatman No. 12 folded filter paper. The dried filter paper with its precipitate was folded and transferred to a $4 \mathrm{ml}$. counting vial. The clear perchloric acid filtrate was collected in a $50 \mathrm{ml}$. centrifuge tube, $5.6 \mathrm{ml}$. of 5 per cent phosphotungstic acid in $2 \mathrm{~N}$ $\mathrm{HCl}$ was added and the contents were mixed by inversion. Five minutes later this mixture was centrifuged at 3,000 rpm for 30 minutes. The clear supernatant was decanted and a $4 \mathrm{ml}$. aliquot assayed for radioactivity. The phosphotungstic acid precipitate was redissolved in $4 \mathrm{ml}$. of 1 $\mathrm{N} \mathrm{NaOH}$ and also assayed for radioactivity.

Calculations were made as follows:

A. per cent.bound to whole plasma $=$

$$
\frac{\text { cpm whole plasma after dialysis }}{\text { cpm added }} \times 100 \text {; }
$$

B. per cent bound to a protein fraction =

$$
\frac{\text { cpm of that fraction }}{\text { cpm whole plasma after dialysis }} \times 100 \text {; }
$$

C. $\mathrm{m} \mu \mathrm{g}$. bound to a protein fraction $=$

$$
\frac{\left(\mathrm{m} \mu \mathrm{g} \cdot \mathrm{Co}^{58} \mathrm{~B}_{12} \text { originally added) }(\mathrm{A})\right.}{10,000}(\mathrm{~B}) \text {; }
$$

D. per cent recovery $=$

$$
\frac{\text { sum of } \mathrm{cpm} \text { from each protein fraction }}{\mathrm{cpm} \text { whole plasma after dialysis }} \times 100 \text {. }
$$

"MP-1" isolation. Plasma was fractionated according to a modification of the method of Weimer, Mehl and Winzler (15). In the in vitro studies, $1 \mathrm{ml}$. of a $\mathrm{Co}^{58} \mathrm{~B}_{12}$ solution containing $20 \mathrm{~m} \mu \mathrm{g}$. per $\mathrm{ml}$. was added to $20 \mathrm{ml}$. of plasma ( $1 \mathrm{~m} \mu \mathrm{g}$. $\mathrm{Co}^{58} \mathrm{~B}_{12}$ per ml. plasma) and the mixture incubated at $4^{\circ} \mathrm{C}$. for one hour. In the in vivo studies, endogenous labeling of plasma with radioactive $\mathrm{Co}^{88} \mathrm{~B}_{12}$ was carried out as described in the section on in vivo labeling.

To one volume of plasma, previously labeled with $\mathrm{Co}^{68} \mathrm{~B}_{12}$ in either of the above manners, 1.2 volumes of saturated $\left(\mathrm{NH}_{4}\right)_{2} \mathrm{SO}_{4}$ were slowly added with mixing. After this mixture had stood at $4^{\circ} \mathrm{C}$. for 16 hours, a precipitate ("Ppt. A") was separated by centrifugation for 30 minutes at $2,000 \mathrm{rpm}$. The supernatant was decanted, reduced to $\mathrm{pH} 4.75$ with $1 \mathrm{~N} \mathrm{HCl}$ and allowed to stand for 16 hours at $4^{\circ}$ C. A precipitate ("Ppt. B") was separated by centrifugation as before and the supernatant was reduced to $\mathrm{pH} 3.7$ with $1 \mathrm{~N} \mathrm{HCl}$. After this supernatant had stood for another 16 hours at $4^{\circ} \mathrm{C}$., a precipitate ("Ppt. C") was again separated by centrifugation. The supernatant was saturated with $\left(\mathrm{NH}_{4}\right)_{2} \mathrm{SO}_{4}$ and the "MP-1" fraction thereby precipitated. This precipitation was facilitated by transferring the $\mathrm{pH} 3.7$ supernatant to a dialysis sac which was then suspended in a beaker containing saturated $\left(\mathrm{NH}_{4}\right)_{2} \mathrm{SO}_{4}$ with an excess of the solid salt. After the sac had remained suspended in solution for 72 hours at $4^{\circ} \mathrm{C}$., a precipitate ("MP-1") formed in the sac and subsequently was separated by centrifugation. Precipitates $\mathrm{A}$ and $\mathrm{B}$, which contained the bulk of the added radioactivity, were redissolved in water and treated with perchloric and phosphotungstic acid in a manner similar to that described above. The resulting precipitates were assayed for radioactivity. Calculations were performed as described above.

In vivo labeling. After overnight fasts, patients were given $0.57 \mu \mathrm{g}$. of $\mathrm{Co}^{58} \mathrm{~B}_{12}$ by mouth and fed one hour later. Blood samples were withdrawn into heparinized syringes at three hour intervals up to 12 hours, then at 24 and 36 hours. After assaying the radioactivity in $4 \mathrm{ml}$. of whole plasma from each sample, 10 to $20 \mathrm{ml}$. of plasma from the sample having the highest $\mathrm{cpm}$ was fractionated according to the previously described methods. The cpm in each fraction were expressed as the per cent of cpm present in whole plasma.

\section{RESULTS}

\section{A. Perchloric-phosphotungstic acid method}

1. In vitro addition of $\mathrm{Co}^{58} B_{12}$. The results obtained by perchloric-phosphotungstic acid precipitation of plasmas (to which $0.120 \mathrm{~m} \mu \mathrm{g}$. $\mathrm{Co}^{58} \mathrm{~B}_{12}$ per $\mathrm{ml}$. had been added) obtained from five subjects with normal serum $B_{12}$ concentrations and five patients with CML and increased $B_{12}$ concentrations are listed in Table I. The phosphotungstic acid precipitates contained a mean of 78 per cent of added $\mathrm{Co}^{58} \mathrm{~B}_{12}$ for the control group and a mean of 77 per cent for the CML group. Perchloric acid precipitates contained a mean of 17 per cent and 11 per cent for the two groups, respectively. Total recovery ranged from 80 to 113 per cent of the added material. The dialysates contained no radioactivity indicating practically complete binding at this concentration.

2. Binding of $\mathrm{Co}^{58} \mathrm{Cl}_{2}$. In order to exclude the possibility that radioactivity present in each fraction represented free cobalt, the binding characteristics of $\mathrm{Co}^{58} \mathrm{Cl}_{2}$ were studied.

When $\mathrm{Co}^{58} \mathrm{Cl}_{2}$ equivalent to the amount of $\mathrm{Co}^{58}$ present in $1 \mathrm{~m} \mu \mathrm{g}$. of $\mathrm{Co}^{58} \mathrm{~B}_{12}$ was added to plasma, and a procedure otherwise identical to that used

\footnotetext{
${ }_{4} \mathrm{Co}^{58} \mathrm{Cl}_{2}$ obtained from Oak Ridge National Laboratory was carrier-free and had an original concentration of 1.26 mc. per ml.
} 
TABLE I

In vitro addition of $0.600 \mathrm{~m} \mu \mathrm{g}$. $\mathrm{Co}^{58} B_{12}$ per $5 \mathrm{ml}$. of plasma $(0.120 \mathrm{~m} \mu \mathrm{g}$. per ml. $)$ followed by perchloric-phosphotungstic acid precipitation

\begin{tabular}{|c|c|c|c|c|c|c|}
\hline \multirow{2}{*}{\multicolumn{2}{|c|}{ Subject }} & \multirow[b]{2}{*}{ Diagnosis } & \multirow[b]{2}{*}{ Serum $B_{12}$} & \multicolumn{2}{|c|}{ Per cent of added $\mathrm{Co}^{58} \mathrm{~B}_{12}$} & \multirow[b]{2}{*}{ Recovery } \\
\hline & & & & $\begin{array}{l}\text { In perchloric } \\
\text { acid } \\
\text { Ppt. }\end{array}$ & $\begin{array}{l}\text { In phospho- } \\
\text { tungstic acid } \\
\text { Ppt. }\end{array}$ & \\
\hline \multirow[t]{3}{*}{ I. } & Normal $B_{12}$ & & $m \mu g . / m l$. & & & \\
\hline & $\begin{array}{l}\text { A } \\
\text { B } \\
\text { J. Q. } \\
\text { O. C. } \\
\text { D. S. }\end{array}$ & $\begin{array}{l}\text { Normal } \\
\text { Normal } \\
\text { Partial resection of ileum } \\
\text { Prostatic carcinoma } \\
\text { Embryonal rhabdomyosarcoma }\end{array}$ & $\begin{array}{l}0.461 \\
0.265 \\
0.299 \\
0.353 \\
0.497\end{array}$ & $\begin{array}{l}16 \\
13 \\
18 \\
17 \\
20\end{array}$ & $\begin{array}{l}79 \\
71 \\
95 \\
80 \\
66\end{array}$ & $\begin{array}{r}95 \\
84 \\
113 \\
97 \\
86\end{array}$ \\
\hline & Mean & & & 17 & 78 & 95 \\
\hline \multirow[t]{3}{*}{ II. } & High $B_{12}$ & & & & & \\
\hline & $\begin{array}{l}\text { L. R. } \\
\text { M. B. } \\
\text { O. F. } \\
\text { O.F. } \\
\text { J. S. }\end{array}$ & $\begin{array}{l}\text { Chronic myelocytic leukemia } \\
\text { Chronic myelocytic leukemia } \\
\text { Chronic myelocytic leukemia } \\
\text { Chronic myelocytic leukemia } \\
\text { Chronic myelocytic leukemia }\end{array}$ & $\begin{array}{r}1.200 \\
2.681 \\
7.825 \\
7.983 \\
13.475\end{array}$ & $\begin{array}{r}6 \\
7 \\
8 \\
13 \\
23\end{array}$ & $\begin{array}{l}83 \\
78 \\
72 \\
73 \\
81\end{array}$ & $\begin{array}{r}89 \\
85 \\
80 \\
86 \\
104\end{array}$ \\
\hline & Mean & & & 11 & 77 & 89 \\
\hline
\end{tabular}

for $\mathrm{Co}^{58} \mathrm{~B}_{12}$ was followed, the recoveries of added material were as follows:

\begin{tabular}{lc} 
Whole plasma (after dialysis) & $\begin{array}{c}\text { Per cent of } \\
\mathrm{cpm} \text { added }\end{array}$ \\
Phosphotungstic acid precipitate & 22.2 \\
Perchloric acid precipitate & 1.89 \\
\hline & 8.84
\end{tabular}

thus demonstrating that with equal amounts of $\mathrm{Co}^{58}$, at the concentrations indicated, that which is added as $\mathrm{Co}^{58} \mathrm{Cl}_{2}$ is not as effectively bound to whole plasma as is $B_{12}$ (22 vs. 95 per cent), and that in contrast to $\mathrm{B}_{12}$, most of the $\mathrm{Co}^{58}$ is found in the perchloric acid precipitate. The fact that the sum of the material recovered in the two precipitates does not equal that which was present in the dialyzed plasma may indicate that perchloric acid had freed some of the bound $\mathrm{Co}^{58}$ in the case of $\mathrm{Co}^{58} \mathrm{Cl}_{2}$.

3. Precipitation in the presence of an excess of nonradioactive $B_{12}$. Because of the possibility that the appearance of $\mathrm{B}_{12}$ in the phosphotungstic acid precipitate of a perchloric acid filtrate represented an artifact introduced by the action of perchloric acid on the original binding protein, by causing release of the bound vitamin, radioactive $\mathrm{B}_{12}$ was allowed to bind with whole plasma, and the subsequent perchloric and phosphotungstic acid precipitations were carried out in the presence of an excess of nonradioactive $B_{12}$.
Two $3 \mathrm{ml}$. aliquots of plasma were combined with $0.1 \mathrm{~m} \mu \mathrm{g}$. of $\mathrm{Co}^{58} \mathrm{~B}_{12}$ per ml. plasma. Both were processed in the same manner (see Methods), but for the fact that following dialysis and prior to the addition of perchloric acid, $100 \mathrm{~m} \mu \mathrm{g}$. of nonradioactive $B_{12}$ per $\mathrm{ml}$. of plasma was added to Sample "A." Recovery of radioactivity in the phosphotungstic acid precipitate was not influenced by the presence of an excess of nonradioactive $B_{12}$.

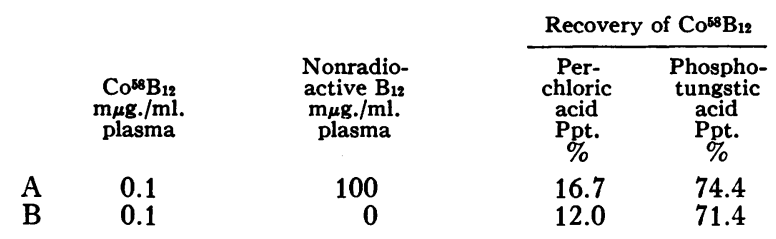

4. In vitro addition of increasing amounts of $\mathrm{Co}^{58} B_{12}$ to normal and $C M L$ plasma. The preceding studies suggest that most of the $\mathrm{Co}^{58} \mathrm{~B}_{12}$ added to plasma at a concentration of $0.120 \mathrm{~m} \mu \mathrm{g}$. per $\mathrm{ml}$. can be recovered in the phosphotungstic acid precipitate. These experiments compare the results obtained with the addition of increasing amounts of $B_{12}$ to plasmas of five normal bank blood donors to that obtained on the plasma from eight patients with CML (Table II and Figures 1 and 2).

a. Bound to whole plasma (Table II). For all subjects studied, virtually all of the added $\mathrm{Co}^{58} \mathrm{~B}_{12}$ 
$B_{12}$ BINDING PROTEIN IN SEROMUCOID






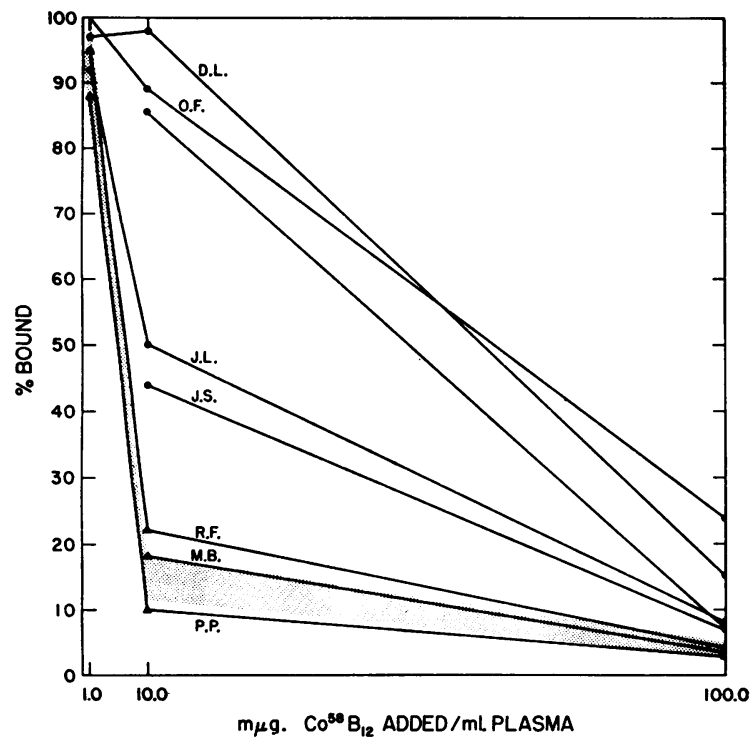

Fig. 1. Per Cent of $\mathrm{Co}^{58} \mathrm{~B}_{12}$ Bound to Whole Plasma Following IN Vitro Addition of 1.0, 10.0 and $100 \mathrm{M} \mu \mathrm{G}$. PER ML. OF Plasma AND Dialysis

The shaded area indicates the range in subjects with a normal serum $B_{12}$. Closed circles represent $C M L$ subjects with a serum $B_{12}$ greater than $2.1 \mathrm{~m} \mu \mathrm{g}$. per $\mathrm{ml}$; closed triangles represent $C M L$ subjects with a serum $B_{12}$ less than $2.1 \mathrm{~m} \mu \mathrm{g}$. per $\mathrm{ml}$.

was nondialyzable (83 to 100 per cent) when added at a concentration of 0.1 or $1 \mathrm{~m} \mu \mathrm{g}$. per $\mathrm{ml}$. plasma; with the addition of larger amounts, the per cent bound fell off sharply in the normal $B_{12}$ concentration group, but remained high in those CML patients with a high serum $B_{12}$. At a concentration of $10 \mathrm{~m} \mu \mathrm{g}$. of added $\mathrm{Co}^{58} \mathrm{~B}_{12}$ per $\mathrm{ml}$. plasma, five normal subjects bound a mean of 16 per cent (range $=12$ to 18 ) of the added material, whereas the eight patients with $C M L$ and a high $\mathrm{B}_{12}$ bound a mean of 47 per cent (range $=$ 10 to 89). When $100 \mathrm{~m} \mu \mathrm{g}$. of $\mathrm{Co}^{58} \mathrm{~B}_{12}$ was added per ml. of plasma, normals bound a mean of 4.5 per cent (range $=4$ to 5) and CML patients bound 9.3 per cent (range $=3$ to 24 ). Within the CML group those subjects with a higher $B_{12}$ concentration bound a greater per cent of the added material than did those with a less striking elevation. Three subjects, R. F., M. B. and P. P., had a pattern similar to that of the normals. They had serum $B_{12}$ concentrations in the 2.0 $\mathrm{m} \mu \mathrm{g}$. per $\mathrm{ml}$. range. The other five CML subjects with increased binding had serum $B_{12}$ concentrations in the $7.0 \mathrm{~m} \mu \mathrm{g}$. per $\mathrm{ml}$. range. b. Bound to phosphotungstic acid precipitate (Table II). The increased binding capacity for added $\mathrm{Co}^{58} \mathrm{~B}_{12}$ by plasma from patients with $\mathrm{CML}$ was found to be associated with an increased recovery of radioactive material in the phosphotungstic acid precipitate. In the five subjects with CML whose plasma bound a greater than normal amount of $\mathrm{Co}^{58} \mathrm{~B}_{12}$, the absolute amount of $\mathrm{Co}^{58} \mathrm{~B}_{12}$ found in the phosphotungstic acid precipitate when $10 \mathrm{~m} \mu \mathrm{g}$. of $\mathrm{Co}^{58} \mathrm{~B}_{12}$ per $\mathrm{ml}$. of plasma was added, had a mean of $5.94 \mathrm{~m} \mu \mathrm{g}$. per ml. plasma, whereas normals at the same concentration of added $\mathrm{Co}^{58} \mathrm{~B}_{12}$ had a mean of $1.14 \mathrm{~m} \mu \mathrm{g}$. per $\mathrm{ml}$. in their phosphotungstic acid precipitate. At a concentration of $100 \mathrm{~m} \mu \mathrm{g}$. of $\mathrm{Co}^{58} \mathrm{~B}_{12}$ per ml. of plasma, the five CML subjects had a mean of $10.01 \mathrm{~m} \mu \mathrm{g}$. per $\mathrm{ml}$. in their phosphotungstic acid precipitate, whereas the normals had a mean of only $2.42 \mathrm{~m} \mu \mathrm{g}$. per $\mathrm{ml}$. The three previously mentioned CML subjects in partial remission had a normal amount of $\mathrm{Co}^{58} \mathrm{~B}_{12}$ bound in their phosphotungstic acid precipitate.

Inspection of Figure 2 demonstrates that in

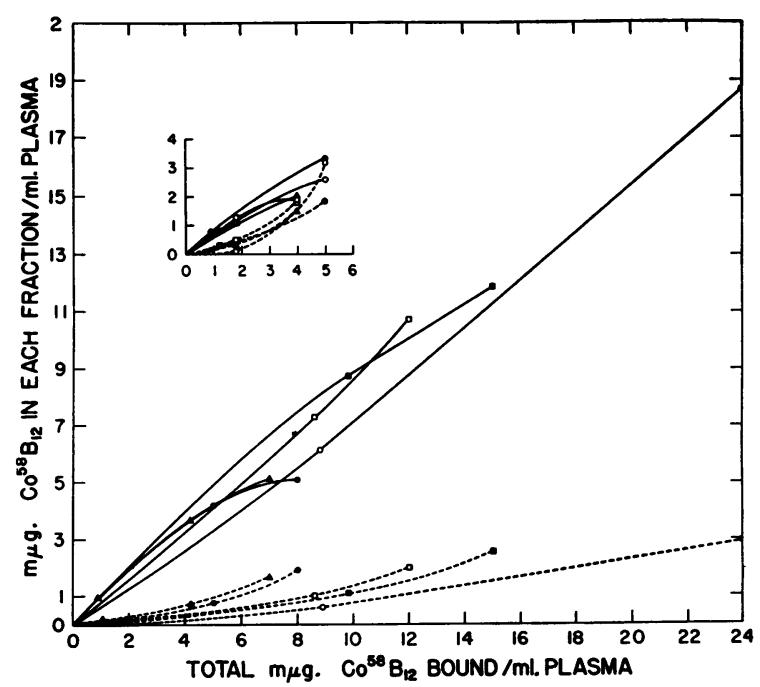

Fig. 2. The Absolute Amount of $\mathrm{Co}^{58} \mathrm{~B}_{12}$ Bound to Phosphotungstic Acid Precipitate, i.e., Seromucoid (Solid Line Curves) and Perchloric Acid Precipitate (INTERRUpted Line CuRves)

The main graph is on sera from five subjects with CML. The insert (same scale) is on five sera with a normal $\mathrm{B}_{12}$ concentration. "Total $\mathrm{m} \mu \mathrm{g}$. $\mathrm{Co}^{58} \mathrm{~B}_{12}$ bound" is that present following dialysis. The three points on each subject's curve correspond to concentrations of 1,10 and $100 \mathrm{~m} \mu \mathrm{g}$. per $\mathrm{ml}$. plasma of added $\mathrm{Co}^{58} \mathrm{~B}_{12}$. 
$B_{12}$ BINDING PROTEIN IN SEROMUCOID

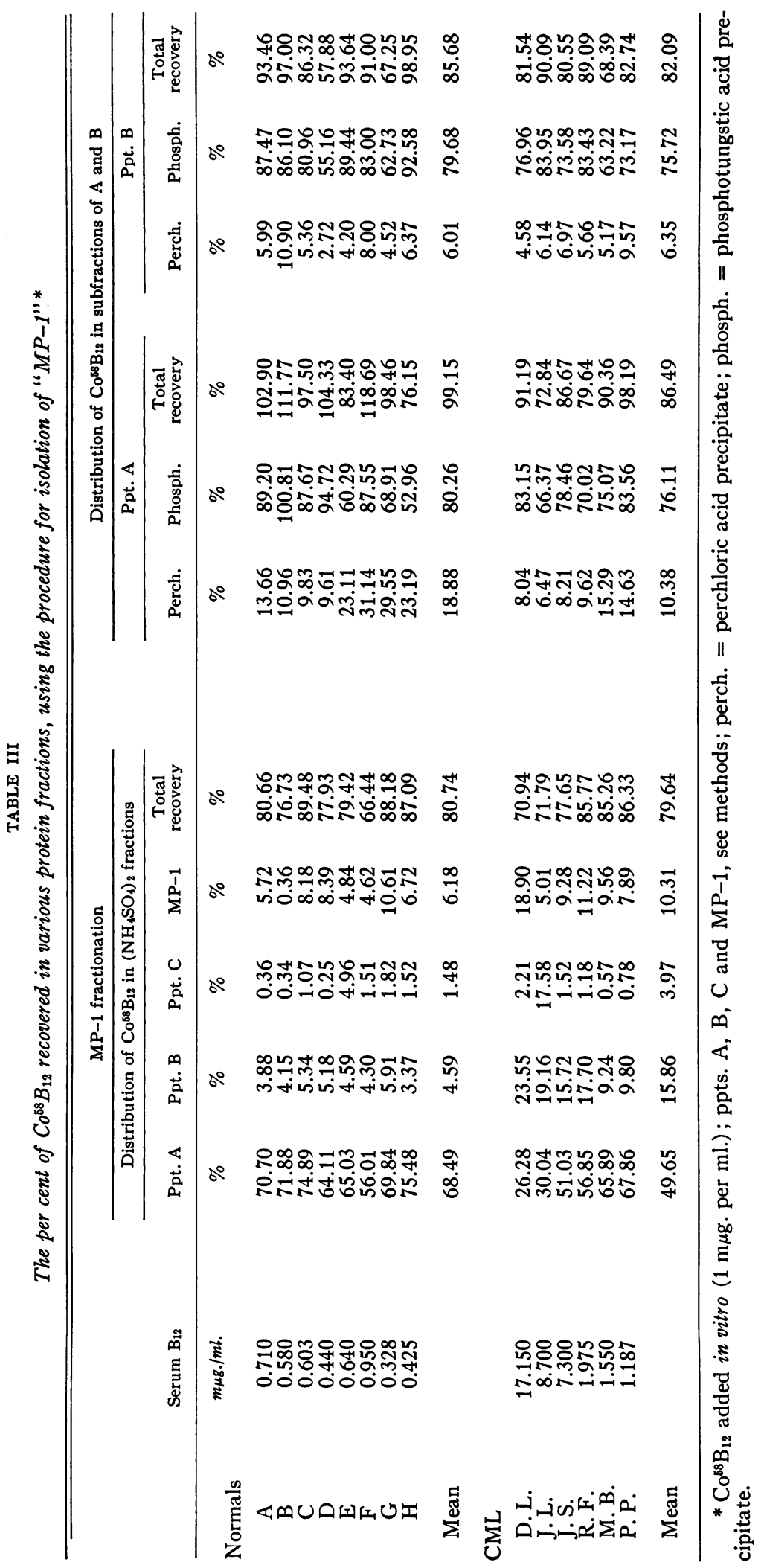


plasma from subjects with a normal serum $B_{12}$ concentration, when more than $2 \mathrm{~m} \mu \mathrm{g}$. of $\mathrm{Co}^{58} \mathrm{~B}_{12}$ is bound per $\mathrm{ml}$. of whole plasma, the per cent of total bound vitamin recovered in the phosphotungstic acid precipitate falls off, whereas that in the perchloric acid precipitate rises. In contrast, in none of the eight subjects with CML did the per cent of bound $B_{12}$ present in the phosphotungstic acid-precipitate decrease until bound $B_{12}$ exceeded $4 \mathrm{~m} \mu \mathrm{g}$. per $\mathrm{ml}$. of plasma, and in two, the per cent did not fall off until bound $\mathrm{B}_{12}$ exceeded $8 \mathrm{~m} \mu \mathrm{g}$. per ml. of plasma.

5. In vivo labeling. Plasma from two subjects, previously labeled in vivo, was fractionated according to the perchloric-phosphotungstic acid method. The results were as follows :

D. S. (embryonal rhabdomyosarcoma)

Whole plasma $(10 \mathrm{ml}$.)

Perchloric acid Ppt.

Phosphotungstic acid Ppt.

\begin{tabular}{cc} 
Serum $\mathrm{B}_{12}=0.478 \mathrm{~m} \mu \mathrm{g} . / \mathrm{ml}$ \\
\hline $\begin{array}{c}\text { cpm- } \\
\text { background }\end{array}$ & $\begin{array}{r}\text { Per cent } \\
\text { recovered }\end{array}$ \\
100 & \\
0 & 0 \\
73 & 73
\end{tabular}

J. L. (CML)

Whole plasma $(20 \mathrm{ml}$.)

Perchloric acid Ppt.

Phosphotungstic acid Ppt.

marized as follows :

$\begin{array}{lcrrrrc} & \begin{array}{c}\text { No. of } \\ \text { subjects }\end{array} & \text { Ppt. A } & \text { Ppt. B } & \text { Ppt. C } & \text { MP-1 } & \begin{array}{c}\text { Total } \\ \text { recovery }\end{array} \\ \text { Normals } & 8 & 68.49 & 4.59 & 1.48 & 6.18 & 80.74 \\ \text { CML's } & 6 & 49.65 & 15.86 & 3.97 & 10.31 & 79.64\end{array}$

They indicate that MP-1 is not the major $B_{12}$ binding substance in either normals or CML's. Most of the radioactivity was found in Ppts. A and $B$. Subsequent treatment of each of these with perchloric acid and phosphotungstic acid resulted in good recovery of radioactivity (82 to 99 per cent) in the phosphotungstic acid precipitate thus further demonstrating the "seromucoid" nature of the binding substance (Table III).

Using the same techniques, fractionation of plasma labeled in vivo was carried out in two subjects :

D. S. (embryonal rhabdomyosarcoma)

Whole plasma $(20 \mathrm{ml}$.)

Ppt. A

Ppt. B

Ppt. C

MP-1

\begin{tabular}{|c|c|}
\hline $\begin{array}{c}\text { cpm- } \\
\text { background }\end{array}$ & $\begin{array}{l}\text { Per cent } \\
\text { recovered }\end{array}$ \\
\hline $\begin{array}{r}200 \\
120 \\
0 \\
0 \\
6\end{array}$ & $\begin{array}{r}60 \\
0 \\
0 \\
3\end{array}$ \\
\hline & $1 \overline{63}$ \\
\hline
\end{tabular}

J. L. (CML)

\section{B. MP-1 fractionation}

The fact that most of the radioactive $B_{12}$ bound to plasma either in vitro or in vivo could be recovered in the phosphotungstic acid precipitate of a perchloric acid filtrate in both normals and CML's indicated that the major plasma $B_{12}$ binding substance was present in the "seromucoid fraction" of plasma. It was, therefore, of interest to determine whether or not the substance was identical with the "MP-1" fraction of seromucoid obtained by Weimer, Mehl and Winzler (15).

Plasma from eight normal bank blood donors and plasma from six patients with CML were labeled in vitro with $\mathrm{Co}^{58} \mathrm{~B}_{12}$ (1 m $\mu \mathrm{g}$. per $\mathrm{ml}$. plasma). The plasmas were fractionated according to a modification of the MP-1 isolation procedure of Winzler and the per cent recovery of added $\mathrm{Co}^{58} \mathrm{~B}_{12}$ in each fraction was determined. The results are listed in Table III and are sum-

Whole plasma $(20 \mathrm{ml}$.
Ppt. A
Ppt. B
Ppt. C
MP-1

DISCUSSION

It has been previously demonstrated that the phosphotungstic acid precipitate of a perchloric acid filtrate of plasma represents approximately 1.5 per cent of the total plasma protein and is rich in glycoproteins (14). This fraction is referred to as seromucoid (14).

Seromucoid is a heterogeneous material. Its major component was isolated in an electrophoretically homogeneous state by a series of ammonium sulfate precipitations by Weimer, Mehl and Winzler (15) and has been designated oroso- 
mucoid or "MP-1." A second component has been demonstrated by electrophoresis and designated “M-2" (17). Experiments in progress suggest the presence of several further components (18).

The data presented in the present study suggest that the plasma $B_{12}$ binding substance in both subjects with normal serum $B_{12}$ concentrations and in CML patients with high serum $B_{12}$ concentrations appears in the seromucoid fraction of plasma. That radioactivity represented the presence of $\mathrm{B}_{12}$ and not simply $\mathrm{Co}^{58}$ was demonstrated by the poor recovery of radioactivity in the seromucoid fraction when plasma was labeled with $\mathrm{Co}^{58} \mathrm{Cl}_{2}$. Because of the possibility that perchloric acid had stripped the $\mathrm{Co}^{58} \mathrm{~B}_{12}$ from its original binding protein thus allowing it to bind secondarily to a glycoprotein, the perchloric acid precipitation was performed in the presence of a high concentration of nonradioactive $B_{12}$. This did not impair recovery of radioactivity in the phosphotungstic acid precipitate. The results of in vivo labeling further support the concept that the native substance is in the seromucoid fraction.

The addition of increasing amounts of $\mathrm{Co}^{58} \mathrm{~B}_{12}$ brought out differences between normals and patients with $\mathrm{CML}$ when concentrations greater than $1 \mathrm{~m} \mu \mathrm{g}$. per $\mathrm{ml}$. of plasma were reached. Thus, at $10 \mathrm{~m} \mu \mathrm{g}$. per $\mathrm{ml}$. control plasma bound 16 per cent of added $\mathrm{Co}^{58} \mathrm{~B}_{12}$, whereas plasma from CML patients with a high serum $B_{12}$ bound a mean of 47 per cent. Studies by others $(3,4)$, also using dialysis methods, have demonstrated a comparable increase in the binding capacity for added $\mathrm{B}_{12}$ ("unsaturated binding capacity") in plasma from CML patients, though variations in the technique used probably account for differences in absolute values obtained by these authors.

With control plasma, when a concentration greater than approximately $2 \mathrm{~m} \mu \mathrm{g}$. of bound $\mathrm{Co}^{58} \mathrm{~B}_{12}$ per ml. of plasma was reached, the per cent bound by the seromucoid fraction diminished whereas the per cent bound by the perchloric acid precipitate increased. This suggests relative saturation of the normal $B_{12}$ binding substance at about the $2 \mathrm{~m} \mu \mathrm{g}$. per $\mathrm{ml}$. level and subsequent secondary binding of additional $\mathrm{B}_{12}$ by perchloric acid precipitable protein. In two CML patients with high serum $B_{12}$ concentrations, however, even at $10 \mathrm{~m} \mu \mathrm{g}$. of bound $\mathrm{Co}^{58} \mathrm{~B}_{12}$ per ml. plasma, there was no decrease in the per cent bound to the seromucoid fraction.

More specific identification of the $B_{12}$ binding material was attempted by using the scheme of Weimer, Mehl and Winzler (15) for the isolation of MP-1. These studies indicate that in sera from subjects with normal $B_{12}$ concentrations the MP-1 fraction is not the major $B_{12}$ binding substance. Instead, the bulk of radioactivity was found in Ppt. A (globulins) and could be separated from it by precipitation with perchloric and phosphotungstic acid. Plasma from CML patients, especially those with a high serum $B_{12}$, displayed a variable pattern with less activity noted in Ppt. A and more in Ppts. B, C and MP-1. The significance of this difference remains to be determined.

Though the present study clearly demonstrates that the plasma $B_{12}$ binding substance appears in the seromucoid fraction of plasma, purification and chemical characterization of the material are required before one can say with certainty that it is a glycoprotein. Similar procedures are necessary to resolve the question of whether the increase in $B_{12}$ binding substance seen in CML represents an excess of the normally occurring material or the presence of a chemically similar but abnormal material having $\mathrm{B}_{12}$ binding capacity. Studies on the further purification of the $\mathrm{B}_{12}$ binding protein by anion-exchange cellulose column chromatography (19) of the seromucoid fraction are now in progress (18).

The data presented appear to be in accord with the previously known facts concerning the plasma $\mathrm{B}_{12}$ binding substance. During electrophoresis at $\mathrm{pH} 8.6$ in veronal, Pitney, Beard and Van Loon (1) found most of the endogenous bound $B_{12}$ in the $\alpha$-globulin fraction of serum as did Ostrowski, Skaryzynski and Zak (9) and Heinrich and Erdmann-Oehlecker (8). In a previous report from this laboratory (10), these findings were confirmed using paper or block electrophoresis followed by microbiologic assay of the endogenous $B_{12}$ present in each fraction. It is known that under the same conditions of electrophoresis the bulk of the seromucoid fraction of plasma has a similar mobility (17). It is of interest that in all of these electrophoretic studies smaller amounts 
of $\mathrm{B}_{12}$ were noted in the albumin and $\beta$-globulin fractions. It is not yet clear whether these fractions bind some $\mathrm{B}_{12}$, since the spreading may be due to imperfections of methods.

The divergent results of Miller and Sullivan (4), who found that following the addition of 15 $\mathrm{m} \mu \mathrm{g}$. of $\mathrm{Co}^{60} \mathrm{~B}_{12}$ per $\mathrm{ml}$. of serum and paper electrophoresis at $\mathrm{pH} 8.6$ in veronal the greatest radioactivity appeared in the $\beta$-globulin fraction in normals and in the $\alpha_{1}$-fraction of sera from CML patients, may reflect the effects of in vitro "overloading" in the normal sera as a result of the unphysiologic concentration of added radioactive $\mathrm{B}_{12}$.

Mendelsohn, Watkin, Horbett, and Fahey (10) have previously reported that when whole serum was fractionated by anion-exchange cellulose (DEAE) column chromatography a single $\mathrm{B}_{12}$ peak was obtained. The latter had the mobility of $\alpha_{1}$-globulin whether obtained from normal or CML sera. On their chromatogram the $\mathrm{B}_{12}$-containing fraction did occur in an area of relatively high protein-bound carbohydrate (hexose) concentration. It did not correspond with the site of elution of orosomucoid (MP-1) thus confirming the present finding that MP-1 is not the major $B_{12}$ binding substance.

Recently, Miller and Sullivan have reported (20) that normal serum mucoprotein remaining after sulfosalicylic acid precipitation of proteins retained 13 per cent of total serum $B_{12}$ binding capacity and CML mucoproteins so prepared retained 59 per cent. It is possible that the mucoprotein techniques used may impair the subsequent binding properties of the material. The present procedure of allowing $B_{12}$ to bind to whole plasma and then fractionating appears to give better recovery of the $B_{12}$ protein complex. The poorer recovery obtained by Miller and Sullivan may also be due to the use of sulfosalicylic rather than perchloric acid.

The fact that Gregory and Holdsworth (21) have described a $B_{12}$ binding protein in sow's milk which has the characteristics of a glycoprotein and that a glycoprotein substance has been isolated from urine (22) which has strong $B_{12}$ binding activity lends further support to the originally proposed hypothesis that various normally occurring $\mathrm{B}_{12}$ binding proteins are chemically similar. The subjects of the exact interrelationship between these substances as well as their physiologic and biochemical functions bear further investigation.

If, as data from the present studies imply, the elevated serum $B_{12}$ levels seen in CML are associated with an increase of a specific $B_{12}$ binding glycoprotein present in the seromucoid fraction, the finding is of interest in terms of the relation between neoplastic disease and glycoprotein metabolism. Total seromucoid as well as MP-1 and MP-2 are known to be elevated in the sera of human subjects with neoplastic disease (23) and also in certain tumor bearing animals (24). Total seromucoid is also known to rise in a variety of diseases associated with traumatic, inflammatory or degenerative tissue changes. These findings have been well reviewed by Winzler (23), Greenspan (25), and Moschides, Stefanini, Magalini and Kistner (26). In addition, however, there is evidence that the carbohydrate to protein ratio of seromucoid may vary in different diseases (27, 28) and also that the relationship between carbohydrate components themselves may vary (29). It has been previously suggested (26) that, since seromucoid is a heterogeneous material, these changes could result from the alteration in a specific component of this fraction. The present data suggest that such is the case in plasma of subjects with CML, in which the $B_{12}$ binding protein is increased. The source of this material as well as the cause for its increase in this disease is at the present time unknown.

\section{SUMMARY}

The fact that intrinsic factor is thought to be a glycoprotein led us to investigate the $B_{12}$ content of the seromucoid fraction of plasma from normal subjects and patients with chronic myelocytic leukemia (CML). When 0.1 to $1.0 \mathrm{~m} \mu \mathrm{g}$. of $\mathrm{Co}^{58} \mathrm{~B}_{12}$ per ml. was added to plasma from six normal subjects and eight patients with CML and free $B_{12}$ was removed by dialysis, 77 per cent and 83 per cent, respectively, of the bound, radioactivity for the two groups was found in the seromucoid fraction. When 10 to $100 \mathrm{~m} \mu \mathrm{g}$. of $\mathrm{Co}^{58} \mathrm{~B}_{12}$ per ml. was added to plasma from patients with $\mathrm{CML}$, an association between the increased binding capacity of this plasma and the increased recovery of radioactivity in the seromucoid fraction 
was demonstrated. The failure to recover substantial radioactivity from the "MP-1" (orosomucoid) fraction following its isolation by ammonium sulfate precipitation from the labeled plasma of normal subjects and patients with CML indicates that orosomucoid is not the major plasma $B_{12}$ binding protein. The fact that the $B_{12}$ binding protein is present in the seromucoid fraction of plasma suggests that it is a glycoprotein. In order to establish this, further purification and chemical analysis of the protein are required. These studies are now in progress.

\section{ACKNOWLEDGMENT}

We are indebted to Mrs. Ella Green for her valuable technical assistance. We are grateful to Dr. Paul Schmidt of the Clinical Center Blood Bank for supplying us with normal plasma samples.

\section{REFERENCES}

1. Pitney, W. R., Beard, M. F., and Van Loon, E. J. Observations on the bound form of vitamin $B_{12}$ in human serum. J. biol. Chem. 1954, 207, 143.

2. Beard, M. F., Pitney, W. R., and Sanneman, E. H. Serum concentrations of vitamin $B_{12}$ in patients suffering from leukemia. Blood 1954, 9, 789.

3. Meyer, L. M., Bertcher, R. W., and Cronkite, E. P. Serum $\mathrm{Co}^{\circ 0}$ vitamin $\mathrm{B}_{12}$ binding capacity in some hematologic disorders. Proc. Soc. exp. Biol. (N. Y.) $1957,96,360$.

4. Miller, A., and Sullivan, J. F. The in vitro binding of cobalt $^{20}$ labeled vitamin $B_{12}$ by normal and leukemic sera. J. clin. Invest. 1958, 37, 556.

5. Mollin, D. L., Pitney, W. R., Baker, S. J., and Bradley, J. E. The plasma clearance and urinary excretion of parenterally administered $\mathrm{Co}^{58} \mathrm{~B}_{12}$. Blood 1956, 11, 31.

6. Miller, A., Corbus, H. F., and Sullivan, J. F. The plasma disappearance, excretion, and tissue distribution of cobalt ${ }^{80}$ labelled vitamin $\mathrm{B}_{12}$ in normal subjects and patients with chronic myelogenous leukemia. J. clin. Invest. 1957, 36, 18.

7. Weinstein, I. B., and Watkin, D. M. Vitamin $B_{12-}$ $\mathrm{Co}^{58}$ absorption, distribution, plasma clearance and excretion in patients with and without elevated plasma $\mathrm{B}_{12}$ levels. Proc. Amer. Ass. Cancer Res. 1958, 2, 355.

8. Heinrich, H. C., and Erdmann-Oehlecker, S. Der vitamin $B_{12}$-stoffwechsel bei hämoblastosen. II. Die intravitable bindung der $\mathrm{B}_{12}$-vitamine an die serum protein-fractionen bei hämoblastosen. Clin. chim. Acta 1956, 1, 311.

9. Ostrowksi, W., Skaryzynski, B., and Zak, Z. Vita$\min B_{12}$ in the protein fractions of human blood serum. Bull. Acad. pol. Sci. Cl. 2 1954, $2,9$.
10. Mendelsohn, R. S., Watkin, D. M., Horbett, A. P., and Fahey, J. L. Identification of the vitamin $\mathrm{B}_{12}$-binding protein in the serum of normals and of patients with chronic myelocytic leukemia. Blood 1958, 13, 740.

11. Castle, W. B. Development of knowledge concerning the gastric intrinsic factor and its relationship to pernicious anemia. New Engl. J. Med. 1953, 249, 603.

12. Pitney, W. R., Beard, M. F., and Van Loon, E. J. The vitamin $B_{12}$ content of electrophoretic fractions of liver homogenates. J. biol. Chem. 1955, 212, 117.

13. Latner, A. L., and Merrills, R. J. Further observations related to the isolation of intrinsic factor muco-protein in Vitamin $\mathrm{B}_{12}$ und Intrinsic Factor, H. C. Heinrich, Ed. Stuttgart, Germany, Ferdinand Enke Verlag, 1957, p. 201.

14. Winzler, R. J., Devor, A. W., Mehl, J. W., and Smyth, I. M. Studies on the mucoproteins of human plasma. I. Determination and isolation. J. clin. Invest. 1948, 27, 609.

15. Weimer, H. E., Mehl, J. W., and Winzler, R. J. Studies on the mucoproteins of human plasma. V. Isolation and characterization of a homogeneous mucoprotein. J. biol. Chem. 1950, 185, 561.

16. Mendelsohn, R. S., and Watkin, D. M. Serum vitamin $B_{12}$ concentrations determined by $L$. leich mannii assay in patients with neoplastic disease. J. Lab. clin. Med. 1958, 51, 860.

17. Mehl, J. W., Golden, F., and Winzler, R. J. Mucoproteins of human plasma. IV. Electrophoretic demonstration of mucoproteins in serum at $\mathrm{pH} 4.5$. Proc. Soc. exp. Biol. (N. Y.) 1949, 72, 110.

18. Weinstein, I. B., Weissman, S. M., and Watkin, D. M. The plasma vitamin $B_{12}$ binding substance. II. Further purification from normal and chronic myelocytic leukemia plasma by fractionation of seromucoid on anion-exchange cellulose columns. In preparation.

19. Sober, H. A., Gutter, F. J., Wyckoff, M. W., and Peterson, E. A. Chromatography of proteins. II. Fractionation of serum proteins on anionexchange cellulose. J. Amer. chem. Soc. 1956, 78, 756.

20. Miller, A., and Sullivan, J. F. Increased binding of vitamin $B_{12}$ by serum mucoproteins in chronic myelogenous leukemia. J. clin. Invest. 1958, 37, 917.

21. Gregory, M. E., and Holdsworth, E. S. A cyanocobalmin-protein complex from sow's milk and dessicated pig stomach. Nature (Lond.) 1954, 173, 830.

22. Anderson, A. J., Lockey, E., and MacLagan, N. F. Some biological properties of the urinary mucoproteins (abstract). Biochem. J. 1955, 60, xli.

23. Winzler, R. J. Determination of serum glycoproteins in Methods of Biochemical Analysis, D. Glick, Ed. New York, Interscience Publishers, Inc., 1955, p. 279. 
24. Baldwin, R. W., and Harris, H. J. Serum protein and glycoprotein changes during growth of experimental tumors in the rat. Brit. J. Cancer. 1958, 12, 99.

25. Greenspan, E. M. Clinical significance of serum mucoproteins. Advanc. intern. Med. 1955, 7, 101.

26. Moschides, E., Stefanini, M., Magalini, S. I., and Kistner, S. A. Content and composition of the mucoprotein fraction of human serum (seromucoid) in disease, with special reference to hematologic disorders. J. clin. Invest. 1958, 37, 127.
27. Shetlar, M. R., Payne, R. W., Bullock, J. A., Patrick, D. R., Hellbaum, A. A., and Ishmael, W. K. Comparative studies of serum polysaccharides in rheumatoid arthritis and degenerative joint disease. J. clin. Invest. 1953, 32, 1208.

28. Greenspan, E. M., and Dreiling, D. A. The serum mucoprotein level in differentiation of hepatogenous from obstructive jaundice. A. M. A. Arch. intern. Med. 1954, 91, 474.

29. Deiss, W. P., and Holmes, L. B. Hexosamines of seromucoid. J. clin. Invest. 1958, 37, 51. 